\title{
Epilepsy, Forgetting, and Convalescence in Ondaatje's Warlight
}

\author{
Jan Gresil S. Kahambing \\ Social Science Unit, Leyte Normal University, Philippines. ORCID: 00oo-0002-4258-0563 \\ Email: jan_kahambing@lnu.edu.ph
}

\begin{abstract}
Michael Ondaatje's Warlight (2018), his latest novel to-date, contains nostalgic elements of strangeness and cartography. In this paper, I short-circuit such themes with health under medical humanities, which heeds a Nietzschean counsel of close reading in literature. To do so, I explore the case of Rachel's illness, namely her epileptic seizures, as an instance that drives her impetus for active forgetting and eventual convalescence. A close hermeneutical reading of the novel can reveal that both of Nietzsche's ideas on active forgetting and convalescence provide traction in terms of what this paper constructs as Rachel's pathography or narration of illness. Shifting the focus from the main narrator, Nathaniel, I argue that it is not the novel's reliance on memory but the subplot events of Nathaniel's sister and her epilepsy that form a substantial case of medical or health humanities.
\end{abstract}

Keywords: Forgetting, Epilepsy, Health, Humanities, Nietzsche, Convalescence

\section{Warlight, Nietzsche, and Health Humanities}

Like dimmed lights in the war, the shadowy or fragmentary narratives of Nathaniel and Rachel's adolescence are war lights within strange conditions. As Nathaniel narrates later in the novel, "we order our lives with barely held stories. As if we have been lost in a confusing landscape, gathering what was invisible and unspoken - Rachel, the Wren, and I, a Stitch - sewing it together in order to survive, incomplete, ignored" (Ondaatje, 2018, 226). It is crucial to begin with this realization as it informs the uncertainty and historical deadlock that coalesce the theme of narration. The 14-year old Nathaniel and Rachel Williams were abandoned by their parents - physically, as they were made to believe - as a form of protection from the pasts that haunt and locate the present. The manner of locating and war references establish the context that Ondaatje's Warlight (2018) is often taken as a valuable lesson on the topographic aspect of war and consequently of life's skirmishes. States the epigraph: "Most of the great battles are fought in the creases of topographical maps." In The English Patient too, when Hana read the 1936 July passage "...the heart is an organ of fire," she was quite focused as she was "submerged within the crabbed handwriting in [...] thick-leaved sea-book of maps and texts" (Ondaatje, 1992, 74). There is also a mapping out of strangeness here, a trajectory that permeates the lives of both. Studies on the novel have pointed out the genre as Bildungsroman, a coming-of-age narrative, but also of the insistence of strange memories that seek to attain clarity.

(c) AesthetixMS 2021. This Open Access article is published under a Creative Commons Attribution Non-Commercial 4.0 International License (http://creativecommons.org/licenses/by-nc/4.o/), which permits non-commercial re-use, distribution, and reproduction in any medium, provided the original work is properly cited. For citation use the DOI. For commercial re-use, please contact editor@rupkatha.com. 
Warlight, however, depicts a unique bildungsroman as the narration of Nathaniel either points towards postnationalist acceptance of foreign 'others' (Whatley, 2019) or a bildung with the "acceptance of incertitude" (Marais, 2020, 94).

However, most of the major notions of the narration are centered on Nathaniel, or Stitch, owing to the nominal imperative that Stitch is responsible, as reflected in his choice, to sew - or map with the intent of security - the fragments together. It might do well in this regard to short-circuit such themes of strangeness and cartography in the perspective of Nathaniel to "completely shatter and undermine our common perceptions" (Žižek's foreword to Zupančič, 2008). Such short-circuit reading, Žižek employs, takes a major notion "through the lens of a 'minor' [...] text ('minor' should be understood here in Deleuze's sense: not 'of lesser quality,' but marginalized, disavowed by the hegemonic ideology, or dealing with a 'lower,' less dignified topic)" (Zupančič, 2008). This paper then takes Nathaniel's sister as the minor text to open hermeneutic horizons. Quite directly, Rachel, Lively (2018) notes, is "a shadowy figure throughout the book." A close reading of her life reroutes the map of focus to her medical condition, episodically portrayed by her fits, as minor notions opening up further understanding other aspects in the novel such as health. That is to say, constructing a narration from Rachel's standpoint can establish under health humanities a different way of mapping narratives - "the term in literature for illness narrative is 'pathography"' (Cole et.al., 2015, 165). Incidentally, there is a link that ties pathographies to diagnosing literature on health and illness here, particularly found in Nietzsche.

"Measure the health of a society and of individuals according to how many parasites they can stand," Nietzsche (1982, \$202) says. His relevance here can be shown in the exemplarity of his condition. That is, he was able to focus on health and the kind of esoteric function it helped him amid suffering from, not syphilis, but several illnesses (Huenemann, 2013). A Nietzschean reading in literature, the arts, and medicine - all three as "a learning laboratory wherein aspirants to the helping professions enter the lives of the ill" (Cole et.al., 2015, 164) - can well reflect his words of practical wisdom. In Medical Humanities, such a reading heeds Nietzsche's own counsel in Dawn "to take time" like surgically précising eyes “... to read slowly, deeply, carefully, considerately, with doors left ajar, with delicate fingers and eyes. ..." (as cited in Cole et. al, 164). More particularly, the topology of strangeness that situates health humanities under a cartographic frame in the novel refers to the "table full of strangers who had altered Rachel" (Ondaatje, 2018, 118). Like parasites, the strangers in Rachel's life imposed foreign changes in her condition in a way that made her figure out how to cope with a healthy response to them and life in general.

The mapping of strangers is arguably a mechanism in the novel that gives it a connection to health humanities. In a short-circuit reading, the paper argues that there are very specific characters within strange situations that help Rachel encounter her pathology and not only construct a narrative of "health, sickness, or illness" but more importantly, this paper shows, of "the support found in the strangest of places, the role and impact of informal caring, and the radical reordering necessary after the dramatic rift that significant illness causes through an individual life" (Crawford, et. al., 2015, 38). Rachel's pathography in this sense hopes to showcase a unique traction that eventually proffers convalescence to recalibrate common conceptions of uncertainty and strangeness or, as the novel's title 
depicts, "in a time capsule of the war years when blackouts and curfews had been in effect, when there was just warlight" (Ondaatje, 2018, 70).

\section{Pathographing Wren's Epilepsy}

In the early naming trope of the novel, Rachel and Nathaniel were branded personal nicknames, mostly having to do with reducing their names with single syllabication. It was intimate, but also reductive, as the name Wren and the act of naming evoke objectification - an entry, in other words, to the map of strangeness by being baptized with a strange name. "Come here, Stitch. Come here, Wren," Rose Williams would bid them, "her personal nicknames," but still under the "suspicion" that, in Nathaniel's words, "was the time Rachel and I felt we had a real mother" (Ondaatje, 2018, 18). The crucial idea here is that Wren as their mother's handpicked name would always be tied to Stitch, that is, as Stitch's sister. This connection implies that Rachel as Wren is a narrative that entangles as well her medical condition. Wren is Nathaniel's sister and her condition is subsumed within this relationship. As the Darter once told Nathaniel after showing him what to do with her, "You need to take care of your sister, Nathaniel" (Ondaatje, 2018, 46), which means to say that Wren needs Stitch.

Throughout the text, Wren's condition was named only thrice (Ondaatje, 2018, 46; 74; 209) as epilepsy. Naming this disease is important because it resides in the shadowy figure of Rachel in the text and therefore needs highlighting. One of the ways in which medical humanities can be practiced in literature is to highlight the illness. Venkatesan and Kasthuri (2018), for instance, have illustrated figurations of a disease - in their case, Alzheimer's - as a form of cultivating alternatives. In the application of health to literature, a focal point can be researched on the development of "literary analysis of specific texts and conditions of traumas (such as epilepsy in literature)" (Crawford, et. al., 2015, 38). It is crucial to draw from Wren's epileptic experiences since "developments in the relationship between medicine and the arts are often driven from below rather than from above" (Bates \& Goodman, 2014, 9).

In the case of Wren's epilepsy, Stitch has noted that at the time, there was more fear of the disease, particularly the effect it has on memory. Epilepsy is a feared disease in literature (Tong, 2014). Pernick's Black Stork (1995), for instance, narrates the refusal of Miriam, who had a mother with hereditary epilepsy, to marry and bear a child, afraid of having a 'baby with epilepsy.' But this is reflected in contemporary legal frameworks as well. Many states in the US legally prohibited marriage to those with epilepsy, as they are deemed "imbeciles" or "feeble-minded" (Cole et.al., 2015, 132). It is this damaging effect that epilepsy was then called a "sacred disease" by witch doctors (Cole et.al., 2015, 63).

Acknowledging her condition, Wren first mentioned the effects it has on her "after reading about them in the library" (Ondaatje, 2018, 46). Stitch described how epilepsy happens in Wren:

Her arms flailed against my face. I grabbed her neck and she froze, fell out of my grip and began shuddering and banging her head and her heels against 
the wood floor. Then a cat-like noise, the pupils slid away, replaced by the whites of her eyes, her arms still flailing. (45)

The Darter's solution to this was straightforward.

He closed the door behind him, knelt down, took my book, the stolen Swallows and Amazons, and jammed it into Rachel's mouth at the moment she gasped for air. He pulled a blanket that was on the bed over her, then lay down beside her and enclosed her in his arms. Until there was only the noise of her breath. (46)

The immediate operation that the Darter had shown, however, does not treat Rachel intimately. Instead, when he said to Nathaniel that he should take care of his sister, it was to take care of Wren whose name is also like a nominal object for their mother. When Nathaniel asked the Darter how he came to know in responding to a fit, the Darter replied, "I had a dog once'-he said it casually - who was epileptic. Now and then he'd go off like a firecracker" (46). This is to say that, like a dog, Wren's condition is no different from nonhuman animals. This is other than the fact that "the Darter learned about such chemical and medicinal information" because "he was a curious man and could extract information from anyone" (74). This is "his familiarity with such drugs and his awareness of my sister's epilepsy," (75) Nathaniel says. Wren could have also been given "Luminal, a tranquilizer used for epileptic seizures," (74) like the Darter's dogs. The Darter is of course a stranger and, aside from the Moth - whom Rachel suspects is a criminal in the beginning - the other strangers that helped in raising them alter Wren's perception of herself. Wren also knew that she was becoming dependent on the help of strangers and this was inscribed in her memory albeit vaguely.

Wren's pathography, moreover, takes a new light in the perception of another stranger, Olive Lawrence, the Darter's lover at the time. Nathaniel "benefited from the clarity of female opinion in this person who had no close connection" to him (209), but Wren also took realizations from her. Olive Lawrence easily had "recognized Rachel's epilepsy by some gesture or quiet evasion in her" (209). She recognized that Wren and her condition might not be the focal standpoint in the strangeness that they are in. Olive Lawrence told Wren something that can make her cope with her condition. Says Olive, "We all have nightmares. For you, dear Rachel, it might be imagining the fear of a seizure. But there need not be fear in a dream, just as there's no danger from the rain while we are under the trees" (51). Olive stood by Rachel 'in the darkness' and appeased her that

there would be no danger, that there was no danger even in dreams or during the unstable tumult of her seizures. There were only crickets in song above us, only the scratch of a badger as it turned in comfort, only the hush and then a sudden whisper of the oncoming rain. (54)

This is after Olive advised that "your own story is just one, and perhaps not the important one. The self is not the principal thing" (52). The book attaches Wren to strange others, even to her brother, who also could not reconcile his identification. Wren's epilepsy is ultimately shown as a narration connected to Nathaniel during the evening when they 
"took off to a seven o'clock screening of a film, and sat in the front row of the Gaumont..." where seizures began to seize Wren: "Rachel, shuddering, a moan, a cow-like noise coming out of her that I knew was going to get louder. She was shaking from side to side" (6o). This time, Nathaniel tried to stop the fits:

I opened her shoulder bag, got out the wooden ruler to put between her teeth, but it was too late. I needed to use my fingers to pry her mouth open, and she was biting down with her thin little teeth. I slapped her and in the midst of her gasp jammed in the wooden ruler and pulled her down to the floor. Above us the plane crashed into the earth...

Her head pulled back, then realizing what it was took it in greedily. The two of us crouched in the dark on that filthy carpet of the Gaumont. I tried lifting her to get her out of there, but she had taken on dead weight, so I lay down on the floor and hugged her to me the way The Darter had done. She looked, in the light that fell from the screen, as if she were still witnessing something terrible. As of course she was, for whenever such episodes occurred, she would later describe to me calmly what she had seen (6o).

The epilepsy was terrible for her. When someone asked, "Who is she?" Wren was again identified as "My sister. It's a seizure." (6o). Nathaniel, narrating the incident years later, was aware that "there are medications now to swerve a body away from this sort of collision, but there weren't any then. None that we knew of, anyway" (6o). Wren's condition was put into the sidelines, momentarily appearing, adding more to the narration that the illness of the society they are in are carved perpetually and chronically by occasional seizures. Despite the advice from strangers, Wren's epilepsy was something that is not negligible. Her condition made her embrace the parasites of her life as if already establishing a symbiotic relationship.

During their abduction - also a seizure by their parent's past - Wren's helplessness doubly resonated in the climactic scene. She was afraid and traumatized as the text described her who "would not leave The Darter. She clung to him and turned away from our mother. She had had a seizure during the kidnapping" (120). There was a sense of recognition on her part, that despite the hazy scenario, Wren knew that her mother and her secrets were in it. It was at this juncture that epilepsy was revealed as a condition of trauma: "when The Darter had risen with her in his arms, and attempted to hand her over to my mother, my sister had begun to weep as if in close proximity to a demon" (120). The details of the event were not clearly detailed even later and it was "more horrific" for Nathaniel.

Epilepsy might have distorted Wren's memory in her narration of events. As Nathaniel tried to stitch out later, "She was not in her right mind, of course, then. She was exhausted. A seizure had been activated in her and she was probably never clear about the details of what had happened" (120). Not only was Rose a trigger of Wren's trauma, but Nathaniel too: "I used to witness that often, when she'd look at me during the moments following a fit as if I were an actual devil" (120). Frequently, Wren's epilepsy damaged her life, the illness having taken over her narrative. The trauma that lingered in her perception was different from Nathaniel's. It was pathography like one of "those love potions in $A$ 
Midsummer Night's Dream had been applied, only what you first saw on waking was not a love object but a source of fear, the source of a pummelling you had been through minutes before" (120).

\section{Forgetting Wren, Rachel's Convalescence}

By the time the second part of the text was introduced, Rachel about 13 years later was already a different person and might have acquired an autonomy that Nathaniel was not able to fully acquire. Rachel's pathography contains unique vicissitudes that are not found in Nathaniel's story. As he says, "If I do not speak of my sister in this story so much, it is because we have separate memories. Each of us witnessed clues about the other we did not pursue" (Ondaatje, 2018, 61). There was still of course the lingering effect of the disease, connected to her memory, but Rachel "tossed away such concerns" (46). In this sense, Rachel's health can be measured by her acting on the events in the first part of the text. After the abduction, Nathaniel "could hear Rachel's muffled crying" as they "were bundled into separate vans, to be delivered to separate destinations" - paths that were going "into another life" (99). He writes that

In any case, Rachel's version of our time at Ruvigny Gardens, though it might nestle with mine in certain ways, would be spoken of in a different tone, with an emphasis on different things. It turned out we would be close only during that early period when we shared a double life. But now, these years later, there is a separateness towards the other, and we fend for ourselves. (61)

Rachel detached herself from Wren, from the years that went by. Says Nathaniel, she "had no desire to reenter our youth. Rachel in her own way had abandoned us, did not wish to go back to what was for her a dangerous and unreliable time" (120). Rachel does away with her childhood memories of her mother and confronts it easily as a reference to be dismissed. It was almost done in a modified process of retrogenesis or the recognition that "human memory, identity and development tends to follow the principle of 'first in, last out' - the idea that our earliest experiences are our most tenacious ones" (Robertson, 2014, p. 232). But this modified process in Rachel was active and she puts her memories at the forefront and chooses to forget them, which is 'first in, first out' instead.

In Nietzschean terms, Rachel was employing active forgetting, which inhibits and temporarily shuts down "the doors and windows of consciousness, [...] and making room for the new" (Nietzsche, 1996a, II, 1). ${ }^{1}$ To be able to move on from her condition, she forgets Wren altogether as its underlying signification. She forgets the betrayals, the secrets and their excessive joys - "Her secret lipstick, a boy on a motorcycle once, her crawling home late giddy with laughter" (61). It was implied that there is a minor thematic of betrayal that Rachel always suspects, being unable to be part of what is going on in the whole scheme, plotted by their mother. Gagiano (2019) not only finds this sense of betrayal in Warlight but also in Ondaatje's Anil's Ghost. ${ }^{2}$ Rachel also forgets this betrayal. Active forgetting, in this sense, opens up a "possibility for the future together with a different understanding of what history is" (Ramadanovic, 2001). The way she forgets this is artful as active forgetting 
plunges into history with fresh eyes (Talay-Turner, 2019), able to comprehend the human condition as if coming from a godly standpoint. That is to say, if epilepsy is a 'sacred' disease, then the act that counters it must be something divine. Nietzsche aptly describes active forgetting as a "divine ability" (Hutchings, 1941).

What Rachel fundamentally does in such ability was to actively shrug away her identification as Wren. Wren was just a "password," (99) uttered in moments of uncertainty, a strange identification where "you end up sometimes not so much repressed, as might be expected, but illegal, you find yourself easily invisible, unrecognized in the world" - which Nathaniel followed up with a rhetoric: "Who was Stitch now? Who was Wren?" (83). It appeared that "in retrospect" Rachel and Nathaniel "were not too different in anonymity from the dogs with their fictional papers" (82-83). Marais $(2015,98)$ claims that "Rachel's resistance to this interpellation is precisely an assertion of the otherness that the name's claim to knowledge seeks to reduce." He explains that Rachel's "choice engenders autonomy, as emerges in her own renunciation of her mother and, moreover, her brother. By renouncing them, she tries to erase the past, to separate herself from it, her parents, and her brother" (Marais, 101). What is characteristic of this choice, for Marais, is that Rachel is acting on a Sartrean framework of action - Rachel is exercising agency which is authentic: "Rachel acts and does so as though alone" (Marais, 101). But there is a caveat because this kind of breaking away is also found in Nathaniel: "like his parents and sister, he acts as though alone, thereby perpetuating the past in the present" (Marais, 102). In effect, Rachel "ironically rehearses her parents' actions [...] through her, the past actually repeats itself in the present. Just as her mother damaged her and her brother by 'abandoning' them, she now damages her mother and brother by 'abandoning' them" (Marais, 101). Like a Sisyphian tragedy, there is a vicious cycle in the lives of the family members. Acting on her agency, "Rachel abandons Rose, she purges herself of her" (Marais, 104). But this is seen as well to the assassin who killed Rose: "Rose's assassin judges, condemns, and executes her and, in this respect, behaves fairly similarly to Rachel, whose 'rough judgement' of her mother, as Nathaniel observes, 'would never abate'" (Marais, 104). Rachel has already spoken of this and expresses her way of Sartrean autonomy:

"We were damaged, Nathaniel. Recognize that." She pushed me gently to the door. "What happened to the girl you never told me about?" I turned away. "I don't know." "You can look. Your name is Nathaniel, not Stitch. I'm not Wren. Wren and Stitch were abandoned. Choose your own life. Even your friend The Darter told you that" (Ondaatje, 2018, 123).

However, Rachel's agency does not stop there, so that this is not the active forgetting that Nietzsche espouses. As Foucault says concerning the difference of Nietzsche's view from Sartre's:

it is interesting to see that Sartre refers the work of creation to a certain relation to oneself the author to himself - which has the form of authenticity or inauthenticity. I would like to say exactly the contrary: we should not have to refer the creative activity of somebody to the kind of relation he has to himself, but should relate the kind of relation one has to oneself to a creative 
activity [...] My view is much closer to Nietzsche's than to Sartre's (Foucault, 1994, 262; Emphasis mine).

Between Rachel and Nathaniel, Rachel devoted herself more to creativity, not just by working as an actress, but by breaking away from the vicious cycle: "her split with their mother is 'irreconcilable,' and she effectively cuts off Nathaniel too" (Lanham, 2018). Exercising active forgetting, Rachel "closed the door on her" (Ondaatje, 121) and Nathaniel. The difference between Nathaniel's narrations to Rachel is the former's reliance on memory and archiving of the past. Nathaniel returns "to that earlier time armed with the present," with the realization that "no matter how dark that world was, you do not leave it unlit. You take your adult self with you. It is not to be a reliving, but a rewitnessing" (Ondaatje, 2018, 96). Under this incomplete 'rewitnessing,' Nathaniel is mistaken to add: "unless of course you wish, like my sister, to damn and enact revenge on the whole pack of them" (96). Warlight's Rachel is not the same as the rewitnessing characters in it such as Nathaniel and Rose. In other words, Rachel's creativity separates herself from the message of Ondaatje's Divisadero as Lee notices (2018) where the author writes that: "We live with those retrievals from childhood that coalesce and echo throughout our lives... We live permanently in the recurrence of our own stories" (Ondaatje, 2007, 116).

The eventual Nietzschean creativity that uniquely characterizes Rachel's resolve is shown more vividly in her convalescence. On the outset, narrating illness, like Oliver Sack's A Leg to Stand On, comes with reflections by proceeding through "a meticulous account of the experience of illness and convalescence" (Cole et.al., 2015, 167). Her convalescence started when she finally renounced the 'schwer' in their lives. Throughout the time Walter, The Moth, had accompanied them - Rachel being closer to him - he cautioned them of the word schwer, as found in the musical scores of Mahler, which means "difficult" or "Heavy" signifying the need "to prepare for such moments" - indeed, a "strange warning to be given, to accept that nothing was safe anymore" (Ondaatje, 2018, 32). The Moth died during the abduction and this was actively forgotten by Rachel through creatively bringing him to life as her convalescence. Rachel's creativity was represented by her child.

In the novel, both Rachel and Nathaniel bore children. Nathaniel's relationship with Agnes Street, the nickname of the girl Nathaniel never told Rachel, had given birth to a child. But this child was also abandoned, left to Agnes and The Darter, and Nathaniel could only think of her as "the young girl" which he "might one day catch sight of, picking up a playing card on the street" (226). Nathaniel was living a Sartrean life, narrated on the basis of his relationship with himself, his authenticity or inauthenticity, his past - his ties to his mother. As he said upon knowing his child with Agnes whose real name was Sophie and the Darter who helped raised her: "What was happening to them was the real story, while I still existed only in the maze of my mother's life" (221).

Rachel, however, has shown convalescence in her child, creatively represented by the name "Walter" and the name's constant support to her narrative.

"Walter," I said quietly. "Yes, dear Walter," she said. I asked her what it was like for her when we were under The Moth's spell, admitting I always felt unsure around him. She turned on me. "Spell? He cared about us. You had 
no idea what was happening. He was the one protecting us. He was the one taking me to the hospital, again and again. You managed to ignore what our parents had done to us" (Ondaatje, 2018, 123; emphasis mine).

Nathaniel did not realize this much as he was focused on his own story. He and Rachel had already "lost each other long ago in those confusions and silences" (Ondaatje, 123). Rachel's child brought her life into a new perspective. Rachel's child, Walter, gave her narrative traction and clarity. This was not just Rachel's story but the healing of her condition, which is to say, not Sartrean but Nietzschean. In Nietzschean terms, the child is "the symbol of creativity, a renewed 'yes' to life, to wonder, to the power to overcome one's self [...] by the power of creation," the "symbol of a renewed creation, who is innocence and forgetfulness, a new beginning, a sport, a self-propelling wheel, a first motion, a sacred Yes" (Nietzsche, $1969, \mathrm{I}, 1)$. There is now a conduit that ties her narrative of convalescence: Epilepsy is a sacred disease, diagnosed by Rachel's active forgetting as a divine ability, and eventually cured by Walter, the child. Contrary to the reactionary move of fearing the disease, Rachel was not afraid of welcoming the possibility of having a baby with epilepsy. Walter, the name of her child and the Moth, was her convalescence. The child reconciled Rachel and Nathaniel and gave their stories distinctiveness. Nathaniel says, “...but now, beside this infant, we were within an intimacy, as when sweat covered her face after a seizure and I would hug her to me. When being wordless had been best" (Ondaatje, 123). At that very moment, Stitch was no longer hugging Wren's epilepsy but Rachel's convalescence. With the intimacy of her child, Rachel herself removed the schwer, the heaviness of their hearts.

“Schumann's 'Mein Herz ist schwer.' You know it, Nathaniel. It's what we used to hear once or twice a week in our house, late at night, with the piano like a thread in the darkness. When you told me you imagined our mother's voice joining in. That was the schwer. (Ondaatje, 123)

Lifting the difficulty that resides in Rachel's heart ${ }^{3}$ was a sense of health. She has reclaimed her humanity, creatively, through renewing the support she got - almost untold in the novel - by Walter. Walter's death was revived in a sense through the child and his name. The name was more intimate, without suspicion, showing Nathaniel that her part of the story, perhaps half of it, was already given fruition and ending. As they bid goodbye, Rachel "was carrying her baby and used the child's small hand to give" Nathaniel "a half wave" (Ondaatje, 2018, 124).

\footnotetext{
Notes

${ }^{1}$ For an explication of active forgetting in promises, see Kahambing (2021).

${ }^{2}$ Although there is a theme of betrayal in Anil's Ghost, there are nonetheless recurring critical agencies or good spectralities that also momentarily give positive traction in the uncertainty of human rights discourse. See Kahambing (2019).

${ }^{3}$ The usual translation is "My soul is dark." I prefer to roughly mean it as "My heart is heavy."
} 
10| Rupkatha Journal, Vol. 13, No. 2, 2021

\section{References}

Bates, V., \& Goodman, S. (2014). Critical Conversations. Establishing dialogue in the medical humanities. In Bates, V., Bleakley, A., and Goodman, S. (Eds.), Medicine, Health, and the Arts. Approaches to the medical humanities (pp. 3-14). Routledge.

Cole, T., Carlin, N., and Carson, R., (2015). Medical Humanities: An Introduction. New York: Cambridge University Press. [Digital Copy]

Crawford, P., Brown, B., Baker, C., Tischler, V., \& Abrams, B. (2015). Health Humanities. Palgrave Macmillan, London.

Foucault, M. (1994). On the Genealogy of Ethics: An Overview of Work in Progress. In P. Rabinow (Ed.), Ethics: Subjectivity and Truth. The Essential Works of Michel Foucault (1954-1984) vol. 1. (pp. 253-280). New York: The New Press.

Gagiano, A. (2019). Postcolonial Illuminations of Past Betrayals in Tan's The Gift of Rain and Owuor's Dust. The Wenshan Review of Literature and Culture, 12(2), 1-27.

Huenemann, C. (2013). Nietzsche's Illness. In Gemes, K., and Richardson, J. (Eds.), The Oxford Handbook of Nietzsche (pp. 63-80). Oxford University Press.

Hutchings, A. (1941). Nietzsche, Wagner and Delius. Music and Letters, 22(3), 235-247.

Kahambing, J.G.S. (2019). Inhuman Rights: Components of Spectrality in Anil's Ghost. Rupkatha Journal on Interdisciplinary Studies in Humanities, 11(1), 71-79.

Kahambing, J.G.S. (2021). Nietzsche on Actively Forgetting One's Promise (Of Love). In S. Hongladarom \& J.J. Joaquin (Eds.), Love and Friendship across Cultures: Perspectives from East and West. Springer.

Lanham, A. (2018). Michael Ondaatje's Haunting Pasts. New Republic. Retrieved from https://newrepublic.com/article/148843/michael-ondaatjes-haunting-pasts

Lee, H. (2018). The Mists of Time, Warlight by Michael Ondaatje. The New York Review of Books. Retrieved from https://www.nybooks.com/articles/2018/05/24/michael-ondaatje-warlight-mists-of-time/

Lively, P. (2018). Wartime Acts, Postwar Retribution: A Mother's Risky Legacy. The New York Times. Retrieved from https://www.nytimes.com/2018/o6/o7/books/review/michael-ondaatje-warlight.html

Marais, M. (2020). Uncertainty and the Time of the Stranger: Michael Ondaatje's Warlight. Mosaic: an interdisciplinary critical journal, 53(1), 91-106.

Nietzsche, F. (1969). Thus Spoke Zarathustra, a book for Everyone and No One. (Trans. R.J. Hollingdale). Penguin Books.

Nietzsche, F. (1982). Daybreak: thoughts on the prejudices of morality (trans. R. J Hollingdale), Cambridge: Cambridge University Press.

Nietzsche, F. (1996). Genealogy of Morals (D. Smith, Trans.). New York: Oxford University Press.

Ondaatje, M. (1992). The English Patient. Vintage Books.

Ondaatje, M. (2007). Divisadero. New York: Knoft. [Digital Copy]

Ondaatje, M. (2018). Warlight. New York: Knopf. [Digital Copy]

Pernick, M. (1995). The Black Stork: Eugenics and the Death of "Defective" Babies in American Medicine and Motion Pictures since 1915. Oxford University Press.

Ramadanovic, P. (2001). From Haunting to Trauma: Nietzsche's Active Forgetting and Blanchot's Writing of Disaster. Postmodern Culture, 11(2), doi: 10.1353/pmc.2001.0005 
Robertson, P. (2014). Music, therapy and technology. An opinion piece. Overview. In Bates, V., Bleakley, A., and Goodman, S. (Eds.), Medicine, Health, and the Arts. Approaches to the medical humanities (pp. 227245). Routledge.

Talay-Turner, Z. (2019). Nietzsche on Memory and Active Forgetting. The European Legacy, 24(1), 46-58.

Tong, R. (2014). The Virtues of the Imperfect Body. In Jones, T., Wear, D., Friedman, L. D. and Vonnegut, M. (Eds.), Health Humanities Reader. New Jersey: Rutgers University Press. [Digital Copy]

Venkatesan, S., \& Kasthuri, R. (2018). "Magic and Laughter": Graphic Medicine, Recasting Alzheimer Narratives and Dana Walrath's Aliceheimer's: Alzheimer's Through the Looking Glass. Concentric: Literary and Cultural Studies, 44(1), 61-84.

Whatley, H. (2019). Postnationalism and the Myth of England in Ondaatje's Warlight. HyperCultura, 8, 1-15.

Zupančič, A. (2008). The Odd One In. On Comedy. Cambridge: MIT Press.

Jan Gresil S. Kahambing is Research Coordinator for the Social Sciences, Political Science, and Values Education at the Leyte Normal University. With occasional scholastic and theological detours, his interests lie within the interdisciplinary junction of contemporary continental philosophy with spectrality, posthuman, indigenous, cross-cultural, and literary studies. His recent publication is a book chapter in Love and Friendship across Cultures: Perspectives from East and West (Springer 2021). 